That goes without saying. If President Bill Clinton were required to make a public speech on, say, his policy on the National Science Foundation, his plans for the more effective management of the Department of Energy, his long-term policy for the huge urban centres of America and the future role of nuclear power in the United States, he would have no time to decide what to do about Bosnia, for Mr Boris Yeltsin and for the 35 million people not covered by health insurance in the United States. So the president can mostly only "send signals". Everybody understands. But some of Clinton's signal-sending in the past few weeks has been disturbing for the sense of casualness it displays.

Take, for example, the case of the National Science Foundation (NSF), supposed only a few weeks ago to be an essential ingredient of the plan to "put America back to work". Just how was never explained, but never mind. But then the President runs into trouble with his political opponents, who are against his $\$ 19$ billion plan (either on the grounds that it is too little or too much). So he cuts his request for funds to Congress almost in half (see page 688). It sounds fair, of course. NSF will probably get something extra, but Clinton's complaisance has undervalued the agency's reputation as an agent of technical change. If half will do as well as a considered whole, why not settle for nothing?

The President's decision about the plutonium-burning reactor at the Argonne National Laboratory's Idaho site (once the National Reactor Testing Center) is less defensible (see page 683). Its budget for next year has been reduced by five-sixths from $\$ 125$ million. When, a few decades from now, the history of nuclear power in the United States is written, people will be mystified that the budget has been so abruptly trimmed, but still not reduced to zero. What, they will be asking, was meant to be the signal? That the Clinton administration was hostile to nuclear power as such, but worried about jobs? Or anxious to keep its options open, but on a scale that would not give offence?

The technical advantages of Argonne's experimental nuclear reactor are plain: it is a model for a breeder reactor that consumes as fuel the long-lived components of spent reactor fuel, the heavier actinides as well as plutonium. As such, it is potentially also a means of getting rid of material that might be used for making weapons. Operating such a novel machine is not child's play. Whatever the designers say, the safety of the equipment must be tested thoroughly before larger versions are built, whenever that may be. If the Idaho project is not a long-term project, it is nothing.

Nuclear power has necessarily now become a long-term business. Dreams that endless energy might already be generated from uranium have been defeated by carelessness in the United States, the Soviet Union and elsewhere. But that state of affairs cannot last. It would be strange if a world unable to burn coal for fear of global warming nevertheless turned its back on the most important source of energy that does not emit carbon dioxide. That is when historians will regret that there is no practical experience of how to operate reactors that consume the long-lived waste from other reactors. Thanks to Clinton's apparently boundless capacity for compromise, it may then be too late.

\section{Life is short}

\section{Eastern Germany should tolerate the temporary indignities of unifications for the sake of the better times ahead.}

IT is natural enough that people in eastern Germany should be disappointed that many of the plum jobs at newly invigorated research institutes in the six eastern Länder should have gone to applicants from what was West Germany. There may be even more substantial cause for grumbling that the flow of relatively junior people from west to east has fallen so far below the target of 10 per cent advised by the Wissenschaftsrat in 1991. But before grumbling turns sour, it is to be hoped that people in eastern Germany will acknowledge that what may seem like a takeover of eastern institutions by carpetbaggers from the west is a manifestation of exceptional circumstances that will soon, with luck, themselves melt away.

The survey described on page 685 provides the first objective evidence of how posts in reorganized research institutes are being filled. Conducted by telephone by Nature's Munich office, the survey provides merely a snapshot of what has happened so far in the staffing of the newly organized institutes. Much may change as more posts are filled. But it is also, in any case, inevitable that the past isolation of the old German Democratic Republic (GDR) from all but the old Soviet bloc will have weighed against the appointment of easterners to senior research posts; their bibliographies will have been thin on publications in recognized journals, their experience of the big wide world will often have been scant, while their experience of the management of research will usually have been different in character from that habitual in the rest of Germany.

Taken together, those pleadings may seem like a justification for bias of a kind. So in a sense they are. But the bias is inevitable, a simple product of the deprivations (as seen from the west) of life in the GDR. After all, has not the great dismaying discovery of the rush to unification been that all kinds of people in the East, from shopkeepers to university professors, have been disadvantaged by the past. A more substantial cause for complaint (if one is really needed) is that, as yet, too little has been done in Bonn to regularize the positions of those in eastern academic institutions who have been accused of political complicity with the old regime, and who have lost their jobs in consequence. There is some justice in Honecker's plaint, at his abortive trial earlier this year, that he should not be tried for following the orders of a then legal government recognized as such in the west.

The best hope, for 'Ossies' and 'Wessies' alike, is that the appointments that have been made to senior positions at eastern institutes are indeed as excellent as they could have been, so that the institutes concerned will prosper. One important objective of the whole exercise, apart from yielding some excellent science, is to assist in the cultural integration of the two parts of Germany. Long before those newly appointed to eastern posts come to retire from work, it is to be hoped that the distinction between 'Ossie' and 'Wessie' will have disappeared. 